\title{
Internalization of character value of social care for madrasah students ibtidaiyah Muhammadiyah in education disruption era
}

\author{
Ratnasari Dyah Utami ${ }^{1}$, Nur Amalia ${ }^{2}$, Harun Joko Prayitno ${ }^{3}$, Triyas Prihandini ${ }^{4}$, Fajar \\ Gemilang Pradana ${ }^{5}$ \\ $\left\{\right.$ rdu150@ums.ac.id'11,na185@ums.ac.id², hjp220@ums.ac.id ${ }^{3}$, triyas.prihandini@gmail.com4, \\ fajar.gemilang@gmail.com\}
}

Faculty of Teacher and Training and Education, Muhammadiyah University of Surakarta, Surakarta, Indonesia ${ }^{1,2,3}$

\begin{abstract}
The purpose of this study are to describe the teacher's efforts in strengthening the social caring character for students of MI Muhammadiyah. This study uses qualitative methods with the techniques of collecting data by using interviews, observation and documentation. To test the validity of research data using triangulation technique of source and triangulation technique. Data analysis techniques in this study consisting of reduction, data presentation and verification. The result of this study indicate that the strengthening of social care characters is implemented through 1) integration of self-development programs through routine activities, spontaneous activities, exemplary and conditioning, 2) integration in subject, 3) integrating school culture through social activities and social action, building community-class harmony, and emphathizing with classmates. The strengthening of social caring character in MI Muhammadiyah as a whole has gone well.
\end{abstract}

Keywords: Internalization Value, Character, Social Care, Students

\section{Introduction}

The factors of character formation and life skills are things that must be considered in an education organization. But in its implementation, character education cannot be fully embedded in the souls of students [1]. This is reinforced by the rise of deviant behaviors committed by students as a result of globalization that occurred in Indonesia. Primary schools as primary education institutions have a duty to produce a generation of morality. One of them is in the aspect of education through schools in order to emphasize character education for their students $[2,3]$.

Character education is inculcated not only through formal education but also through informal and non-formal education. It means that character education should not only be a responsibility in the world of education, but a shared responsibility between government, society, families, and schools. The teacher as the main actor and determinant of the success or failure of the learning process if it is associated with character education has a very important role. In addition to having the skills, understanding and competence regarding the character of the teacher must also have a noble character in itself.

Character is a mindset, attitude or action that is inherent in a person with very strong and difficult to remove [4]. Characters mark the application of values into behavior forms [1]. 
Character is also referred to as psychiatric qualities, morals or character that can distinguish the character and character of one person with another [5]. From the description above it can be concluded that the reinforcement of character is a planned, conscious and responsible way of training and guiding students to apply character values conceptually and contextually in accordance with educational goals. Social care is an act or attitude to provide assistance to other people and communities in need [6]. Social care is a tangible form of human consciousness as social beings who cannot live alone [7]. From the description above it can be concluded that social care is an act done consciously to others who need it.

The implementation of social care character education is done by teachers through strengthening verbal and nonverbal values. Verbal reinforcement through providing motivation, advice, stories, reprimands, punishment, and praise [8]. Strengthening non-verbally through habituating behavior and exemplary. The implementation of social care character education includes: 1) integration of personal development programs such as greeting habits, routine infaq every Monday and Thursday, social services every Ramadan, 2) integration in subjects by linking social care characters in the subjects of Pkn, IPS and Indonesian, 3) the integration of school culture by facilitating social activities such as when Eid al-Adha distributes sacrificial meat [9].

MI Muhammadiyah in Sukoharjo seeks to implement the strengthening of social care characters in every learning activity for students [2]. The era of disruption is a phenomenon when the community shifts its activities which were originally real activities into activities in cyberspace. This also has an impact in the world of education, where children become more comfortable in cyberspace so the social care of children is greatly decreased. For this reason, there is a need for teacher efforts to strengthen the character of social care [3]. Strengthening social care character is intended to form a spirit of generosity and a high sense of social care so that it can be applied and embedded in daily life both within the school environment and outside the school environment [4]. The teacher as a mentor must set an example for his students, caring and respecting each other in the classroom environment. To strengthen the social care character, the school carries out various efforts through activities every day. The purpose of this study is to describe the efforts of teachers in internalizing the character of social care for students at MI Muhammadyah Sukoharjo [2,10,11].

This research was conducted for 4 months starting from March to June 2019. The schools that were the object of research were the nadrasah ibtidaiyah in Sukoharjo Regency, represented by Gon Gonim, MIM PK Wir in ogunan, and PK Kartasura MIM. Data collection methods used in this study were interviews, observation and documentation. Interviews were conducted with school principals, teachers and students. In this interview the speakers were: 1) school principals in three schools that were sampled, to obtain information on background, vision and mission, teacher competencies and models for strengthening social care characters in MI Muhammadiyah in Sukoharjo, 2) Teachers from grade 1 to grade 6 in each school are 20 people to find out the involvement of teachers in planning and implementation in strengthening social care character in MI Muhammadiyah Sukoharjo, 3) students in grades 1 through grade 6 total 60 MI Muhammadiyah students in Sukoharjo to get information about the competencies provided and the attitude of teachers in treating their students.

The observation referred to here is observing the implementation of the internalization of the values of social care characters, changes in the character of students and things that support the implementation of the internalization of social care characters in MI Muhammadiyah Sukoharjo. Documentation as a complement to interviews and observations in qualitative research. The documentation referred to here is about the surrounding documents regarding the strengthening of social care character and the interview process takes place. To test the validity of the data, researchers used triangulation techniques to test the data by checking the 
data to the same sources with different techniques. In addition, researchers also triangulate the source to test the data by checking the data that have been obtained through several sources.

\section{Methods}

The research conducted is a qualitative research with a phenomenological design. Qualitative research focuses on social phenomena and on voting on the feelings and perceptions of participants under study. Through the design of phenomenology, researchers conducted research with a focus on seeing the efforts of teachers in internalizing the value of social care characters in MI Muhammadiyah in Sukoharjo Regency.

This research was conducted for 4 months starting from March to June 2019. The schools that were the object of research were the madrasah ibtidaiyah in Sukoharjo Regency, represented by Gon Gonim, MIM PK Wir in ogunan, and PK Kartasura MIM. Data collection methods used in this study were interviews, observation, and documentation. Interviews were conducted with school principals, teachers and students. In this interview the speakers were: 1) school principals in three schools that were sampled, to obtain information on background, vision and mission, teacher competencies and models for strengthening social care characters in MI Muhammadiyah in Sukoharjo, 2) Teachers from grade 1 to grade 6 in each school are 20 people to find out the involvement of teachers in planning and implementation in strengthening social care character in MI Muhammadiyah Sukoharjo, 3) students in grades 1 through grade 6 total $60 \mathrm{MI}$ Muhammadiyah students in Sukoharjo to get information about the competencies provided and the attitude of teachers in treating their students.

The observation referred to here is observing the implementation of the internalization of the values of social care characters, changes in the character of students and things that support the implementation of the internalization of social care characters in MI Muhammadiyah Sukoharjo. Documentation as a complement to interviews and observations in qualitative research. The documentation referred to here is about the surrounding documents regarding the strengthening of social care character and the interview process takes place. To test the validity of the data, researchers used triangulation techniques to test the data by checking the data to the same source with different techniques. In addition, researchers also triangulate the source to test the data by checking the data that has been obtained through several sources.

\section{Results and Discussion}

This research was conducted at MI Muhammadiyah in the Sukoharjo region, represented by MIM Gonilan, MIM PK Wirogunan, and PK MIM Kartasura. Judging from the facilities and infrastructure owned by MI Muhammadiyah in the Sukoharjo region as a whole the conditions are adequate and quite good. This research was conducted in three schools that have different characteristics. MIM PK Wirogunan represents MIM where most of the students live near the center of the crowd such as markets, terminals, highways, etc. This is the cause of the lack of students social care level because parents protect their children tightly. MI Muhammadiyah Gonilan represents MI which includes schools in middle condition both in infrastructure and achievements. This school has a vision of "Being the best partner for the community in forming students who are righteous and excel". The MIM PK Kartasura represents schools that are already quite conducive in various ways. These characteristics can be seen in the Table 1. 
Table 1. Characteristics of Respondent Schools

\begin{tabular}{lcl}
\hline \multicolumn{1}{c}{ School } & Category & \multicolumn{1}{c}{ Characteristics } \\
\hline MIM Gonilan & Less & $\begin{array}{l}\text { The location of the school near the center of the crowd, } \\
\text { education and social status of parents is low, the level of } \\
\text { social care is still lacking } \\
\text { The condition and facilities of school infrastructure are } \\
\text { quite supportive, social status and secondary parental } \\
\text { education } \\
\text { RiM PK Wirogunan }\end{array}$ Intermediatively conducive in various aspects \\
MIM PK Kartasura & Well &
\end{tabular}

In the learning process, the teachers at MIM implement learning activities while having fun, planting and strengthening character and active learning. This was demonstrated by the implementation of good habits such as learning good manners in behavior and speech, as well as monitoring the personality of students conducted every day.

Internalization of the value of social care characters can be done in several forms. The form of internalizing social care characters can be seen from the integration of social care character education through self-development programs, integration in subjects, integration in school culture [12,13]. Students are accustomed to applying character values into their daily lives, schools are required to conduct activities related to the intended character $[14,15]$. Coaching is not only taught in class but also continued in habituation in the school environment [16]. The same thing was done by MIM in Sukoharjo, were to internalize the value of this social care character has done various things such as creating a self-development program, integration in subjects, and integration in school culture.

To internalize the value of social care characters in MI Muhammadiyah Sukoharjo, several efforts are needed by the school in the form of:

1. Personal Development Program

Some of the school activities in the self-development program consist of:

a. Routine Activities

This activity is carried out continuously in school. This activity includes the custom of greeting and greeting when meeting with friends and teachers, welcoming the morning, obligatory prayers and sunnah in the congregation, Friday morning infectious, and social services every Ramadan. In addition, there is also other habituation as carried out by MIM PK Wirogunan namely reading the pledge every morning before learning begins. Pledges at the school began with the Creed, read the Al-Fatiha, the Prayer of Ba'iat and the Prayer of Learning, the Promise of Muhammadiyah Students, sang the song of the sun, sung MI's march, and ended with singing the national song. One of the contents of the Muhammadiyah Student Promise is "Willing to sacrifice and help others". This is quite effective to remind students to always have a caring attitude towards others.

Getting used to good daily activities is one way to strengthen the caring character of students [3]. In order to be able to internalize the character of social care in students, these activities must be familiarized and carried out continuously so that students will get used to it [14].

b. Spontaneous Activities

This activity was carried out at that time as a form of correction for bad actions which included giving a reprimand to a busy friend himself, giving understanding to students who were indifferent, and giving praise to students who were willing to help others. This activity is usually carried out when the teacher or other education 
staff learns that there is an act which is not good from the students which must be corrected at that [15].

This activity was carried out at that time as a form of correction for bad actions which included giving a reprimand to a busy friend himself, giving understanding to students who were indifferent, and giving praise to students who were willing to help others. This activity is usually carried out when the teacher or other education staff learns that there is an act which is not good from the students which must be corrected at that time [4].

Exemplary is a good action as a teacher to be a good example for their students because this model will contribute positively to the development process of student psychology, especially in the habituation and formation of student behavior by giving good examples such as helping others, visiting sick friends, help friends who are struggling, and polite words $[17,18]$. There were four things in the effort to develop character education in relation to personal development, one of which was the example, attitudes and behavior of students imitating the behavior and attitudes of teachers and education personnel [2].

In this MI the conditioning with non-physical things is in the form of direct experience and stories, advice, habituation of mutual cooperation and direct examples in obeying discipline in school. To support the implementation of character education, the school must be conditioned to support the activity. Schools must reflect the life of cultural values and national character $[8,11]$.

This is reinforced by observations that show that routine activities carried out at MI Muhammadiyah Sukoharjo include 3S habituation (smiling greetings) when meeting, giving respect, speaking politely and performing dhuha and dhuhur prayers in congregation at the mosque. In addition, the teacher also greets and greets students at the school gate, provides a box for routine infaq every Friday, opens the lesson with greetings, provides motivation and attention to students. Spontaneous activities carried out at MI Muhammadiyah Sukoharjo include when there are students who are sick, other students help deliver to UKS, the teacher reprimands and advises students who are busy when the learning process takes place, the teacher gives direction and advice when there are students who fight, besides the teacher also reprimands students who do not respect their friends when presenting in front of the class. Exemplary conducted at MI Muhammadiyah Sukoharjo includes the participation of teachers in routine infaq activities every Friday, the teacher also provides examples to always help students who are experiencing difficulties and need help. Conditioning that is carried out at MI Muhammadiyah Sukoharjo includes conditioning in the classroom that allows students to work together and help each other, besides that the teacher also accustoms students to greet each other when they meet.

2. Integration in Subjects

Integration in each subject is taken from each subject by reviewing the lesson plan and syllabus used in the learning process. At MI Muhammadiyah Sukoharjo, the teacher has included the values of social care characters in the written and conditional RPP, and the teacher has also integrated the values of social care characters in the subject. Internalization of the character of social care is done with stories, motivation, and advice so that students care more about each other. Not only linking the value of socially caring characters in general subjects such as Pkn and IPS but also linking with Al-Islam subjects such as Fiqh, Al-Qur'an and Hadith. In the Pkn subject, the teacher internalizes the 
character of social care through examples of sharing attitudes in daily life. In social studies subjects, the teacher internalizes social care attitudes by contributing to victims of natural disasters, visiting orphanages and nursing homes, visiting sick friends, helping teachers erase the blackboard, and other social care attitudes. In Fiqh learning by teaching students to respect each other when a friend is presenting their findings in front of the class. This is reinforced by the results of observations that show that in MI Muhammadiyah Sukoharjo there are already several teachers who include the value of social care characters in the lesson plan and some are still conditional.

The development of cultural education values and national character are integrated in each subject matter of each subject [2]. These values are included in the syllabus and lesson plans. In order to achieve a character that has been fading so far the strengthening of character values needs to be included in the RPP. Each subject has its own values which will be instilled in students. This is because the priority focus of each subject must have different characteristics [6].

Internalization of the value of social care characters in learning is shown by the teacher teaching students to share with each other when there are friends who do not carry stationery, teach children to respect friends who are expressing opinions in front of the class, teach to share and help friends when there are friends who are having difficulties, advising students not to ridicule other friends.

3. Integration in School Culture

The school has carried out various social activities covering a variety of things. Based on the results of interviews with school principals and teachers, it is obtained that the school has integrated social care characters into the school culture. This is reinforced by the results of observations in schools that show that schools have integrated social care traits such as, social service to underprivileged residents around the school during Ramadan, collecting money and goods for victims of natural disasters, visiting friends or teachers who are sick, infaq routine weekly every Friday, lending friends a stationary when in class, no fuss in the classroom during the learning process, respecting friends who express their opinions and presentations in front of the class, not busy themselves, respecting teachers when explaining material, sharing food and drinks during recess , lending friends who do not carry pocket money, helping friends who are troubled when receiving lesson material and helping school cleaners by not littering the yard and throwing trash in its place.

School culture can be said as thoughts, words, attitudes, actions and hearts of each school community which is reflected in the spirit, behavior and symbols as well as the unique slogan of their identity [8]. Character values in school culture include activities carried out by school principals, teachers and students. School programs can run smoothly because of harmonious relations, cooperation and mutual benefits between the school and the community. Thus schools can be said to be successful in strengthening the social care character of their students [18]. Character education and attitudes in schools are an important foundation in the socio-cultural development of a nation [19], [20].

\section{Conclusion}

Based on the results of research conducted at MI Muhammadiyah Sukoharjo through interviews, observations and documentation, then from this study it can be concluded that the 
efforts made by teachers in internalizing the values of social care characters include: 1) Personal development programs in the form of routine activities, spontaneous activities, exemplary, and conditioning such as exchanging greetings and greetings, giving Friday morning activities, giving reprimands, motivation and advice, giving examples for students. 2) Integration in subjects, including internalization into general subjects (Pkn and IPS), as well as Al-Islam subjects (Al-Qur'an, Hadith and Fiqh). 3) Integration in school culture by carrying out social activities within the school and community environment such as social services in the month of Ramadan, collecting assistance to victims of natural disasters, and weekly infaq. Overall the internalization of the values of social care characters in MI Muhammadiyah Sukoharjo has been going well.

\section{References}

[1] Pala A. The need for character education. Int J Soc Sci Humanit Stud 2011;3:23-32.

[2] Fauzi AR, Zainuddin Z, Atok R Al. Penguatan karakter rasa ingin tahu dan peduli sosial melalui discovery learning. J Teor Dan Praksis Pembelajaran IPS 2017;2:79-88. doi:10.17977/um022v2i22017p079.

[3] Prayitno HJ, Ngalim A, Sutopo A, Pangestu DW, Jamaluddin N, Ali AH. Directive politeness act strategy in the discourse of education column in national newspaper as the formation of students character in Indonesia. Humanit Soc Sci Rev 2019;7:349-62. doi:10.18510/hssr.2019.7241.

[4] Masrukhan A. Pelaksanaan pendidikan karakter peduli sosial di SD Negeri Kotagede 5 Yogyakarta. MIOSR J Econ Financ 2016;3:2812-20. doi:https://doi.org/10.3929/ethz-b-000238666.

[5] Agung L. Character education integration in social studies learning. Hist J Pendidik Dan Peneliti Sej 2018;12:392. doi:10.17509/historia.v12i2.12111.

[6] Dalyono B, Lestariningsih ED. Implementasi penguatan pendidikan karakter di sekolah. Bangun Rekaprima 2017;3:33-42. doi:10.1111/j.1469-8986.1974.tb00542.x.

[7] Al-Mukhaini EM, Al-Qayoudhi WS, Al-Badi AH. Adoption of social networking in education: A study of the use of social networks by higher education students in Oman. J Int Educ Res 2014;10:143-54. doi:10.19030/jier.v10i2.8516.

[8] Sari YM. Pembinaan toleransi dan peduli sosial dalam upaya memantapkan watak kewarganegaraan (civic disposition) siswa. J Pendidik Ilmu Sos 2016;23:15-26. doi:10.17509/jpis.v23i1.2059.

[9] Tabi'in A. Menumbuhkan sikap peduli pada anak melalui interaksi kegiatan sosial. J Soc Sci Teach 2017;1:39_ 59

[10] Azizah ZF, Karyanto P, Prayitno BA, Sapartini RR. Penguatan kesiapan berperilaku ramah lingkungan siswa SMA melalui pengembangan pedagogi spesifik berbasis PjBL pada mata pelajaran ekologi. Proceeding Biol Educ Conf 2017;14:415-23.

[11] Rahman GF. Pendidikan nilai kepedulian sosial pada siswa kelas tinggi di sekolah dasar negeri Muarareja 2 Kota Tegal tahun ajaran 2013/2014. 2014.

[12] Setiawan MA, Vien R, Suryono H. Penerapan model analisis dilema moral terhadap sikap peduli sosial siswa pada kompetensi dasar menampilkan sikap positif berpancasila dalam kehidupan berpasyarakat. Paedagogia 2017;20:88. doi:10.20961/paedagogia.v20i1.16602.

[13] Abu L, Mokhtar M, Hassan Z, Darmanita Suhan SZ. How to develop character education of madrassa students in Indonesia. J Educ Learn 2015;9:79. doi:10.11591/edulearn.v9i1.768.

[14] Indriani DS. Keefektifan model think pair share terhadap aktivitas dan hasil belajar IPS. J Elem Educ 2015;4:27-31.

[15] Windiyani T, Novia L, Permatasari A. Penggunaan media pembelajaran gambar fotografi pada mata pelajaran ilmu pengetahuan sosial siswa sekolah dasar. JPSD 2018;4:91-101.

[16] Frengky. Model pembelajaran matematika siswa kelas satu sekolah dasar. Psikologi 2008;35:151-63.

[17] Fallis A. Membangun karakter melalui integrasi ilmu dalam pembelajaran. J Chem Inf Model 2013;53:168999. doi:10.1017/CBO9781107415324.004.

[18] Omeri N. Pentingnya pendidikan karakter dalam dunia pendidikan. J Manajer Pendidik 2015;9:464-8. doi:10.1002/pon.3619.

[19] Prayitno, H.arun Joko, et all. "Directive Politeness Act Strategy in The Discourse of Education Column in National Newspaper as The Formation Of Students' Character in Indonesia”. Humanities \& Social Sciences Reviews, Vol 7, No 2, 2019, pp 349-362.

[20] Leng, Yap Kwee \& Nor Aishah Buang. "The Involvement In Tunas Niaga Activities and The Entrepreneurial Attitude Among Secondary Schools". IJOLAE Indonesian Journal on Learning and Advanced Education. Vol.1, No.1, pp 15-25, 2019. 
